\title{
Appraising the Qualities of Social Work Students' Theoretical Knowledge: A Qualitative Exploration
}

Citation for published version (APA):

Van Bommel, M., Boshuizen, E., \& Kwakman, K. (2012). Appraising the Qualities of Social Work Students' Theoretical Knowledge: A Qualitative Exploration. Vocations and Learning, 5(3), 277-295.

https://doi.org/10.1007/s12186-012-9078-9

\section{DOI:}

$10.1007 / \mathrm{s} 12186-012-9078-9$

Document status and date:

Published: 01/10/2012

Document Version:

Peer reviewed version

\section{Document license:}

CC BY

Please check the document version of this publication:

- A submitted manuscript is the version of the article upon submission and before peer-review. There can be important differences between the submitted version and the official published version of record. People interested in the research are advised to contact the author for the final version of the publication, or visit the DOI to the publisher's website.

- The final author version and the galley proof are versions of the publication after peer review.

- The final published version features the final layout of the paper including the volume, issue and page numbers.

Link to publication

\section{General rights}

Copyright and moral rights for the publications made accessible in the public portal are retained by the authors and/or other copyright owners and it is a condition of accessing publications that users recognise and abide by the legal requirements associated with these rights.

- Users may download and print one copy of any publication from the public portal for the purpose of private study or research.

- You may not further distribute the material or use it for any profit-making activity or commercial gain

- You may freely distribute the URL identifying the publication in the public portal.

If the publication is distributed under the terms of Article 25fa of the Dutch Copyright Act, indicated by the "Taverne" license above, please follow below link for the End User Agreement:

https://www.ou.nl/taverne-agreement

Take down policy

If you believe that this document breaches copyright please contact us at:

pure-support@ou.nl

providing details and we will investigate your claim.

Downloaded from https://research.ou.nl/ on date: 26 Apr. 2023 
Appraising the Qualities of Social Work Students' Theoretical Knowledge:

A Qualitative Exploration

Marijke van Bommel

Henny P.A. Boshuizen

Kitty Kwakman

Author created version of article in Vocations and Learning / DOI 10.1007/s12186-012-9078-9

M. van Bommel (corresponding author)

HAN University of Applied Sciences, P.O.Box 6960, 6503 GL Nijmegen, The Netherlands. E-mail: Marijke.vanBommel@han.nl

H. P. A. Boshuizen

Open University Netherlands.

K. Kwakman

Zuyd University of Applied Sciences, The Netherlands 


\begin{abstract}
Higher professional education aims to prepare students for entering practice with an adequate theoretical body of knowledge. In constructivist programmes, authentic learning contexts and self-directed learning are assumed to support knowledge learning and the transition from education to practice. Through an in-depth exploration, this case study aimed at defining and assessing the qualities of social work students' theoretical knowledge at initial qualification. Participants were final-year bachelor's students $(n=18)$ in a constructivist professional programme of social work. Students' knowledge concerning a real-life practical case was elicited through an interview and a form of concept mapping. A six-step procedure was used for a qualitative appraisal of students' knowledge with the assistance of seven expert teachers. During this procedure an instrument for analysing knowledge qualities was developed, comprising 13 aspects representing four features of expert knowledge: extent, depth, structure, and critical control. Results showed that 13 students received high appraisals for their knowledge extent and depth. Only 4 students received high appraisals for knowledge structure and critical control. 5 Students who received overall lower appraisals seemed inhibited to show their knowledge qualities by preoccupations with self-concerns about their own professional role. Conclusion is that the majority of students needs more learning support for knowledge structure and critical control than offered by their constructivist programme. Further research is needed into the personal factors that influence students' theoretical knowledge learning and which knowledge qualities can be reached by young adults in a four year educational programme.
\end{abstract}

Keywords Theoretical knowledge - Higher professional education - Social work Qualitative research - Constructivist education. 


\section{Theoretical knowledge in constructivist education}

In higher professional education theoretical knowledge is an important part of the professional knowledge base that is required for initial qualification. Theoretical knowledge consists of facts, concepts, principles and theories, and is important for two reasons (Novak 1998; Tynjälä 2009). First, to do the job well: to understand what happens and why, to make informed decisions of what actions to take, to account for choices and results and to seek improvements (Bereiter 2002; Eraut 2004). Second, to examine practice critically in order to seek improvements (Edwards 1998).Theoretical knowledge is an integral part of professional knowledge, along with practical/experiential knowledge residing in skills, and self-regulative knowledge that includes metacognition and self-reflection (Tynjälä 2009). During education, connecting theoretical and other forms of professional knowledge is not easy, nor without effort. Yet it is deemed essential for high quality practice performance (Eraut 1994).

Therefore the field of our study, social work education, has a long tradition of using authentic learning contexts, of incorporating substantial periods in practice, and of encouraging active ways of learning. Authentic problems and tasks and active, self-directed learning have been used in various constructivist instructional designs: casework, project-, problem-, and competency-based learning (Biggs 2003; Lave 2009; Moust and Schmidt 1998; Simons, Van der Linden and Duffy 2000; Van Merriënboer 1997). Authentic learning contexts and active, self-directed learning are assumed to help students make the transition from education to work and prepare them for life-long learning. (Lave 2009; Tynjälä 2009; Simons et al. 2000). Recently, doubts have been expressed about the effects of authentic contexts and self-directed learning on the quantity and quality of students' theoretical knowledge. Will students acquire a solid knowledge base or only skills to look things up? Is the focus on instrumental application of knowledge too strong, at the cost of knowledge as a system-of-meaning in itself (Maton and Moore 2010; Wheelahan 2010)? Is it better to offer students direct knowledge instruction (Kirschner, Sweller and Clark 2006)? Tobias and Duffy (2009) state that these questions are not yet answered by empirical research in real-life education. These critiques in combination with a lack of empirical evidence induced us to explore the qualities of students' theoretical knowledge after attending a constructivist social work programme in a Dutch university of applied sciences. The aim of this study was to find ways to appraise students' theoretical knowledge for its suitability for entering practice. We examined the following questions: 
What are the qualitative features of social work students' theoretical knowledge at the end of a constructivist professional bachelor's programme? To what extent are these features in accordance with demands on theoretical knowledge as part of professional knowledge at initial qualification?

A few words need to be added on the context of our study. In the Netherlands social work is taught by universities of applied sciences. Social work is not an academic discipline in itself. The core of its body of knowledge is derived from several academic disciplines such as psychology, sociology, psychopathology, pedagogy and philosophy, including worldviews, values and moral/ethical considerations. The social work body of knowledge also includes factual knowledge of societal and work conditions, including legislation, policies, protocols, financial resources (Cosis Brown 1996; Parton and O'Byrne 2000; Sectorraad HSAO 2008). Besides this core knowledge, specialist knowledge is available for many different work field contexts and clients, specific problems, intervention methods and evidence of their effectiveness (Otto, Polutta and Ziegler 2009; Van Ewijk 2010). Students' choices, for example of work field for internship and minor, define which part of this specialist knowledge is learned.

\section{Social work knowledge}

In social work, the role and status of theoretical knowledge is determined by the domain's illstructured and normative character. Social work situations are complex and highly specific, with unique combinations of actors and influencing factors that make full understanding virtually impossible (Strasser and Gruber 2004; Payne 2009). Social workers deal with multiple dilemmas arising from conflicting interests, values, and goals between individuals, groups and society at large. For example in combining care and control in forensic psychiatry or in deciding whether or not to intervene in youth care (Parton and O'Byrne 2000; Payne 2009; Van Ewijk 2010). Social work's body of knowledge contains a variety of approaches. It offers no single prescriptions for how to think or act, but multiple explanations and solutions. Circumstances for knowledge application vary considerably from one instance to another. Interventions must be negotiated with clients and in accordance with ethical and legal demands. (Parton and O’Byrne 2000; Payne 2009; Spiro and DeSchryver 2009; Otto et al. 2009). A social worker's theoretical knowledge is a repertoire from which an appropriate selection needs to be made (Eraut 1994). Spiro and DeSchryver (2009) state that in an ill- 
structured domain knowledge must be combined and adapted to unique situations and people, an essentially constructive process.

\section{Learning social work knowledge: personal and situated}

In theories of professional development learning theoretical knowledge is seen as an integral part of becoming a professional. Professional development is a highly personal and interactive process which is situated in the context of physical actions and professional communities (Daley 2001; Dall'Alba and Barnacle 2007; Hager and Hodkinson 2009). Professional knowledge cannot be separated from the learner as a person. "Knowing is inhabitated; we cannot step outside it. But it is also transformative - it can change who we are." (Dall'Alba and Barnacle 2007, p. 682). In professions like social work, counselling, or teaching, a professional's personal characteristics, values and involvement highly influence the quality of interactions and thus professional effectiveness (Strasser and Gruber 2004; Otto et al. 2009; Van Ewijk 2010). The integral character of professional development requires that theoretical knowledge is learned simultaneously with other forms of professional knowledge such as practical and self-regulative knowledge (Lave 2009; Tynjälä 2009). During professional education, theoretical knowledge needs to be connected to real practice, making use of the affordances for learning of the workplace in combination with formal educational activities (Billett 2001; Eraut 2012; Lave 2009; Wenger 1998). Social work knowledge is about people and their problems in life, but it is more than just daily-life personal experience. For a professional, knowledge of single occasions is not enough. Multiple experiences make students move beyond what Bereiter (2002) calls episodic knowledge: the memory of personally experienced events and reasoning by analogy and association. Students need to experience many different real-life situations to develop the ability to detect patterns of resemblance and connect these to theoretical explanations (Spiro and DeSchryver 2009). However, both the personal and situated way of learning theoretical knowledge constructivist education are criticized. They emphasise the instrumental use of knowledge which inhibits paying enough attention to knowledge as a system of meaning in itself (Wheelahan 2010). As Eraut (1994) states, introducing knowledge only when it is required "destroys its coherence, leads to an uncritical, half-understood acceptance of ideas, and avoids practice in the appropriate selection of knowledge from the repertoire." (p. 120). Such knowledge does not enable critical examination of practice (Edwards 1998; Wheelahan 2010). Furthermore, situated and personal ways of learning are very time-consuming and lead 
to constant dilemmas of dividing available time over content. This leads to the question what can be expected of students' theoretical knowledge in a four year programme.

\section{Defining knowledge qualities for initial qualification}

Research on expertise development offers four useful concepts to examine knowledge qualities: knowledge extent, depth, structure and critical control (Alexander 2003; Bereiter and Scardamalia 1993; Eraut 1994; Schmidt and Boshuizen 1993). Knowledge extent and depth refer to the amount of knowledge: the range of topics (extent) and how much is known about each topic (depth). Experts have a wide and deep knowledge base, which allows them to act quickly and accurately, without overlooking important elements of a problem or situation (Boshuizen 2004). Knowledge structure refers to the coherence of knowledge as a system-of-meaning in itself (Wheelahan 2010). Experts have meaningfully interrelated knowledge networks. Such structures facilitate knowledge activation and application, especially in stressful real-life circumstances under time-pressure (Eraut 1994). In illstructured domains like social work, knowledge structures do not contain hierarchical, predictive relations but rather patterns of reciprocal influences with more or less explanatory power. (Eraut 1994; Parton and O’Byrne 2000; Strasser and Gruber 2004). Critical control concerns keeping one's knowledge up to date. As expertise develops, knowledge tends to become routinized, intuitive and implicit or, ultimately, tacit and very difficult to explicate (Schön 1983). Critical control has become more important with increasing speed of knowledge development and professionals being expected to participate in knowledge development (Bereiter 2002; Wenger 1998). In social work, the call for more evidence-based practice and accountability increased the demands on reflexivity and critical control over knowledge (Otto et al. 2009; Taylor and White 2000).

We used these four qualities of expert knowledge to formulate what is expected of the theoretical knowledge of starting social workers. Social work is a broad domain, therefore a social worker's knowledge needs to be extensive in order to assess problems and situations without overlooking important elements. A range of situational facts about people and their circumstances, the agency's and country's policies, protocols, financial resources and legislation needs to be covered, as well as generic core knowledge of human development, behaviour and interaction, intervention approaches, values and worldviews. When knowledge needs to be broad, depth cannot be reached for all topics alike. Knowledge depth is required for the above described generic core knowledge at three work levels: micro/client, 
meso/agency, and macro/society. Knowledge depth as in specialisation can only be expected for a limited number of subjects, such as specific age groups, problems and intervention methods. Knowledge structure is needed for the generic core knowledge. First, as a prerequisite for analysing people's complex circumstances, problems and behaviours including consideration of the interplay between the three work levels - clients, agency and society. Second, for underpinning choices of interventions and explaining and evaluating their outcomes. Critical control is wanted for critical analysis of practice and for ongoing professional development. These considerations were the starting point for the method design in our study.

\section{Method}

The present study is an explorative multiple case study (Yin 2003), using qualitative methods. A combined inductive/deductive approach (Corbin and Strauss 2008; Miles and Huberman 1994) was used, employing social work experts to define detailed standards for demands on students' professional knowledge at initial qualification. Quantification of qualitative data was included in the analysis (Chi 1997).

\section{Participants}

Participants were 18 students of the Institute of Social Studies of HAN-University of Applied Sciences, equally divided over three professional bachelor's programmes of Social Work: Cultural and Social Education $(n=6)$; Social Educational Care $(n=6)$; Social Work and Services $(n=6)$. All students volunteered to participate, 3 spontaneously after an invitation by e-mail,15 after encouragement by teachers who were asked by the researchers to invite students they looked upon as representative. All participants (15 females and 3 males) were in their final year, 17 students varying in age from 20 to 24 years, 1 student aged 27. Secondary vocational education was the prior education of 8 students, and 10 students had attended general secondary education. Students' grade-point averages varied from 6.6 to 8.3 on a 10-point scale. In respect to gender, age, prior education and grade-point averages the participants were representative for the student population $(n=205)$ of our case study. Their programmes had a constructivist design, using authentic learning contexts and self-directed learning. About one third of the programme was situated in practice.

Instruments 
Two instruments were used to elicit students' knowledge: a semi-structured qualitative interview (Rubin and Rubin 2005), and a visual mapping task resembling concept mapping (Novak 1998). In the visual mapping task a third instrument, a domain knowledge list, was used to offer students an opportunity to recognise knowledge they had not recalled spontaneously. This domain knowledge list was compiled by the researchers from overviews of social work theory for bachelor's programmes and validated by experts from education ( $n$ $=13)$ and practice $(n=20)$ who declared the knowledge list to be a compact representation of social work's theoretical knowledge base (Anonymous). In order to capture students' theoretical knowledge as applied in a real-world situation, the interview and the visual mapping task were about a case from the students' own practices, and aimed at eliciting -in an unobtrusive way- as much knowledge as possible in the context of a student's own specific case.

Data gathering procedures

Participants were asked to prepare themselves by bringing a case from their own practice which they had experienced as difficult, or challenging. All participants were interviewed by the same interviewer (the first author). Each session had the same order: (1) interview, and (2) visual mapping task.

Opening question for the interview was to describe the own case as detailed as possible, followed by probes for elaboration and follow-up questions about predetermined topics, if these were not mentioned spontaneously: clients and their situation, problem explanations, own actions and results, which actions the students -in retrospect- would now have taken, and which knowledge they had missed at the time of the case (Rubin and Rubin 2005). An open atmosphere was created, to avoid that students felt like being tested. Throughout the interviews, the interviewer avoided judgmental reactions. All interviews were transcribed verbatim.

In the visual mapping task students were asked to arrange what they thought were important elements in their case-description on a large sheet of paper (paper format A1). Next they were asked to connect these elements and describe the nature of the connections, while thinking aloud. The interviewer encouraged them to write down utterances about connections between elements, using the students' own wordings. This was done because concept mapping is a difficult task to perform without prior training (Ruiz-Primo 2004). All thinkaloud utterances were transcribed verbatim. After finishing the mapping task, the students 
were shown the above mentioned domain knowledge list and invited to add knowledge topics from the list to their visual map. 12 Students added topics, 6 students did not.

Analysis

Because students' materials consisted of unique cases with different content, they were aggregated during analysis to a more abstract, generic level, to make comparison possible. To ensure the quality of the analysis process, we used a procedure of six iterative steps: (1) content analysis of students' interview transcripts and visual maps by individual experts using a predefined analysis instrument; (2) content analysis by individual experts in discussion with a second expert; (3) analysis of the outcomes of step 2, resulting in an extension of the analysis instrument and a qualitative knowledge profile for each student, enabling comparison between students; (4) quantification of the qualitative profiles; (5) independent reliability and validity check of step 1 to 4 ; and (6) statistical analysis. We will first describe the analysis procedure and then the resulting instrument.

Analysis procedure

In step 1 the interview transcript and visual map of each student was individually analysed by two experts, using an analysis form containing nine knowledge aspects, derived from literature as indicators of knowledge extent, depth, structure and critical control (Alexander 2003; Bereiter and Scardamalia 1993; Eraut 1994; Schmidt and Boshuizen 1993). The participating experts were seven senior teachers from three social work programmes, with ample experience in assessing final-year students. Each expert analysed the material of 4 to 6 students.

In step 2 a pair of two experts elaborately discussed their step-1 appraisals of a single student's material in sessions of approximately one hour per student. These discussions led to qualitative appraisals of each student's knowledge, underpinned by experts' arguments. The discussions were transcribed verbatim.

In step 3 the researchers qualitatively analysed the discussion transcripts of step 2 . This analysis led to adding 4 knowledge aspects and to the extraction of criteria for the appraisal of all 13 knowledge aspects in regard to bachelor's-level. A qualitative profile of each student's knowledge for the 13 aspects was composed.

In Step 4 the researchers quantified the student profiles by scoring the knowledge aspects on an ordinal 5-point rating scale for each aspect, using the criteria formulated in Step 3. 
Step 5 was a validity and reliability check of step 1 to 4 by two independent domain experts: senior teachers from a master of social work programme. These specialists examined a representative selection of student materials, expert analyses, and student scores to examine if they were able to replicate the appraisal procedure. The remarks of the domain experts led to slight alterations and fine-tuning of the profiles, which added to the validation and reliability of the analysis procedure and instrument.

In step 6 Spearman's correlation coefficients (SPSS 17.0) were computed to explore correlations between students' scores on the 13 knowledge aspects, as well as between these scores and two student features: prior education and grade-point averages. Hierarchical cluster analysis (between-groups linkage, SPSS 17.0) was performed to identify groups of students and clusters of aspects. Finally, knowledge aspects were conceptually clustered for the four features of expert knowledge: extent, depth, structure, and critical control (Miles and Huberman 1994).

Table 1 Aspects of knowledge quality and their relation to the four features of expert knowledge

\begin{tabular}{|c|c|c|c|c|}
\hline \multicolumn{2}{|c|}{$\begin{array}{l}\text { Features of } \\
\text { expert knowledge }\end{array}$} & $\begin{array}{l}\text { Aspects of } \\
\text { knowledge quality }\end{array}$ & $\begin{array}{l}\text { Initially } \\
\text { formulated } \\
\text { aspects }\end{array}$ & $\begin{array}{l}\text { Aspects that } \\
\text { emerged from } \\
\text { analysis }\end{array}$ \\
\hline & \multirow{4}{*}{$\begin{array}{l}\text { Critical } \\
\text { Control }\end{array}$} & Professional language & & $\mathrm{X}$ \\
\hline \multirow{12}{*}{ Extent } & & Explicit concepts & $\mathrm{X}$ & \\
\hline & & Unarticulated knowledge & & $\mathrm{X}$ \\
\hline & & Situational facts & $\mathrm{X}$ & \\
\hline & \multirow{6}{*}{ Depth } & Relevance & $\mathrm{X}$ & \\
\hline & & Completeness of narrative & $\mathrm{X}$ & \\
\hline & & Work levels & $\mathrm{X}$ & \\
\hline & & Accounting for actions & $X$ & \\
\hline & & Viewpoints & & $\mathrm{X}$ \\
\hline & & Role awareness & & $\mathrm{X}$ \\
\hline & \multirow{3}{*}{ Structure } & Analytical perspective & $\mathrm{X}$ & \\
\hline & & Complexity & $\mathrm{X}$ & \\
\hline & & Completeness of structure & $\mathrm{X}$ & \\
\hline
\end{tabular}


An instrument for appraising knowledge qualities

Table 1 shows an overview of all knowledge quality aspects and their connections to the four features of expert knowledge. Nine knowledge aspects were initially derived from literature, four additional aspects emerged from analysis. The resulting analysis instrument, 13 aspects and criteria for their appraisal, is included in Appendix A. Here follows an abbreviated description of aspects and criteria. The nine initially formulated aspects are: Explicit concepts: the number of theoretical concepts explicitly mentioned in the narrative (extent; critical control); Situational facts: the number and range of situational, contextual facts mentioned in the narrative (extent); Relevance: the professional relevance of narrativeelements as to content, including the conciseness of the narrative (extent; depth); Completeness of the narrative: the inclusion of all elements essential for a professional description of the case (extent; depth); Work levels: the number of work levels (personal; organisational; societal) and connections between these levels that are included in the narrative (depth); Accounting for actions: the elaborateness of deliberations and explanations of professional actions (depth); Analytical perspective: the explicit use of a methodical cycle and feedback loops to depict and explain the case and own actions within it in the visual map (structure); Complexity: the number of relevant elements and work levels plus connections between these in the visual map, varying from simple/linear to complex/systemic (structure); and Completeness of structure: the inclusion of all elements essential for a professional depiction of the narrative's structure in the visual map (structure). The four aspects that emerged from analysis are: Professional language: use of language, varying from informal, concrete-only and verbose to formal, methodical, abstract, and concise (critical control); Unarticulated knowledge: theoretical knowledge which is not explicitly mentioned, but indirectly recognisable in described actions and deliberations (extent); Differentiation in Viewpoints: the inclusion of viewpoints of different actors and different work levels (depth); and Role awareness: the awareness and handling of one's own professional role in connection to other professionals and contextual circumstances (depth).

\section{Results}

A first result consisted of extended individual profiles of students' theoretical knowledge, with summaries and quotations from analysis-protocols and a numerical score for each aspect. Each profile depicts a detailed qualitative portrait of a students' theoretical knowledge 
situated in real-life context, composed of aspects that enable qualitative appraisal as well as comparison between students. The profiles are too lengthy to include as a whole, but Appendix B shows two examples of appraisals for quality aspect relevance: the professional relevance of narrative-elements as to content, including the conciseness of the narrative, which is linked to two knowledge features extent and depth. The first student in this example received a high score (5) for relevance, because the case description contains many relevant elements which are presented in a methodical way and from a well-expressed view on the matters at hand. The second student received a medium score (3) for the same aspect. This student's case description also contains many relevant elements of the work process, but at some point the description lacked recognition of an important legal protocol.

Students' cases were representative of social work practice: difficult, complex situations and client problems, moral dilemmas, lack of ready-made solutions, large responsibilities. For example, students described clients with severe psychiatric and social problems or addictions, with complicated family relationships and multi-cultural settings; and clients who were unwilling to cooperate. They described a variety of own roles, including service provider for clients; team member; coordinator of colleagues and volunteers; advocate for clients' interests.

\section{Correlations}

Table 2 shows that high positive correlations were found between knowledge aspects belonging to the same knowledge features: knowledge extent ( $r_{\mathrm{s}}$ between .5 and .9$)$, knowledge depth ( $r_{\mathrm{s}}$ between .8 and .9), knowledge structure $\left(r_{\mathrm{s}}=.9\right)$. This is an indication that the aspects of each feature are interrelated. The two aspects indicating critical control did not show significant correlations. No significant correlations were found between the studentfeatures level of prior education (A) and grade-point averages (B) and any of the knowledge aspects. 
Table 2 Significant correlations (Spearman's $r_{s}$ ) between 2 student features (A and B) and 13 knowledge aspects

\begin{tabular}{|c|c|c|c|c|c|c|c|c|c|c|c|c|c|c|c|}
\hline & A & $\mathrm{B}$ & 1 & 2 & 3 & 4 & 5 & 6 & 7 & 8 & 9 & 10 & 11 & 12 & 13 \\
\hline A Prior education & -- & & & & & & & & & & & & & & \\
\hline B Grade-points averages & & -- & & & & & & & & & & & & & \\
\hline 2. Explicit concepts & & & & -- & & & & & & & & & & & \\
\hline 3. Unarticulated knowledge & & & & & -- & & & & & & & & & & \\
\hline 4. Situational facts & $-.5^{*}$ & $-.5^{*}$ & & $.5^{*}$ & $.7^{* *}$ & -- & & & & & & & & & \\
\hline 6. Completeness of narrative & & $-.5^{*}$ & $.5^{*}$ & $.5^{*}$ & $.7^{* *}$ & $.8^{* *}$ & $.9^{* *}$ & -- & & & & & & & \\
\hline 7. Work levels & & & & & $.6^{* *}$ & $.9^{* *}$ & $.8^{* *}$ & $.9^{* *}$ & -- & & & & & & \\
\hline 8. Accounting for actions & & & $.5^{*}$ & & $.7^{* *}$ & $.7^{* *}$ & $.9^{* *}$ & $.9^{* *}$ & $.9^{* *}$ & -- & & & & & \\
\hline 9. Viewpoints & & & & $.5^{*}$ & $.7^{* *}$ & $.8^{* *}$ & $.8^{* *}$ & $.9^{* *}$ & $.9^{* *}$ & $.9^{* *}$ & -- & & & & \\
\hline 10. Role-awareness & & & & & $.7^{* *}$ & $.8^{* *}$ & $.8^{* *}$ & $.9^{* *}$ & $.9^{* *}$ & $.9^{* *}$ & $.9^{* *}$ & -- & & & \\
\hline
\end{tabular}

$* \mathrm{p}<.05 ; * * \mathrm{p}<.01$ 
Table 3 Overview of student groups' scores on a five-point scale )* for aspect clusters and stand-alone aspects

\begin{tabular}{|c|c|c|c|c|c|c|c|c|c|}
\hline \multirow[b]{2}{*}{$\begin{array}{l}\text { Student } \\
\text { Gr.H }\end{array}$} & \multicolumn{8}{|c|}{ aspect cluster 1} & \multirow[b]{2}{*}{$\begin{array}{l}\text { Situationa } \\
\text { Facts }\end{array}$} \\
\hline & $\begin{array}{l}\text { educ- } \\
\text { ation }\end{array}$ & $\begin{array}{l}\text { point } \\
\text { averages }\end{array}$ & $\begin{array}{l}\text { Role } \\
\text { awareness }\end{array}$ & $\begin{array}{l}\text { View } \\
\text { points }\end{array}$ & $\begin{array}{l}\text { Work } \\
\text { levels }\end{array}$ & $\begin{array}{l}\text { Accounting } \\
\text { for actions }\end{array}$ & $\begin{array}{l}\text { Completeness } \\
\text { of narrative }\end{array}$ & Relevance & \\
\hline H.1 & voc. & 7,3 & 5 & 5 & 5 & 5 & 5 & 5 & 4 \\
\hline H. 2 & gen. & 7,2 & 5 & 5 & 5 & 5 & 5 & 5 & 5 \\
\hline Н.3 & gen. & 7,1 & 5 & 5 & 5 & 5 & 5 & 5 & 5 \\
\hline H. 4 & voc. & 7,6 & 5 & 4 & 4 & 5 & 4 & 5 & 5 \\
\hline
\end{tabular}

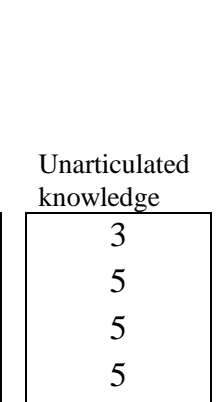

aspect cluster 2

\begin{tabular}{|c|c|}
\hline $\begin{array}{l}\text { Explicit } \\
\text { concepts }\end{array}$ & $\begin{array}{l}\text { Completeness } \\
\text { of structure }\end{array}$ \\
\hline 5 & 5 \\
\hline 4 & 4 \\
\hline 4 & 4 \\
\hline 2 & 3 \\
\hline
\end{tabular}

aspect cluster 3

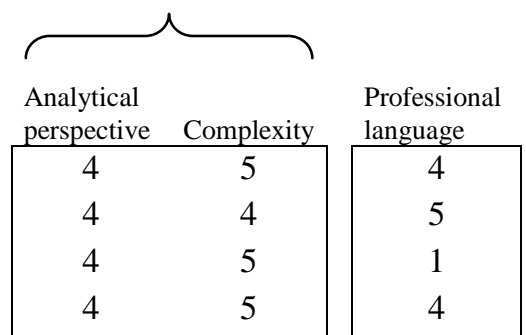

\section{Gr.HM}

HM.1 gen.

HM.2 gen.

\begin{tabular}{l|llllll|}
7,6 & 5 & 4 & 4 & 5 & 4 & 5 \\
7,4 & 4 & 4 & 3 & 4 & 4 & 5 \\
\hline
\end{tabular}

\begin{tabular}{l}
2 \\
4 \\
\hline
\end{tabular}

\begin{tabular}{l|}
4 \\
4 \\
\hline
\end{tabular}

\begin{tabular}{|ll|}
\hline 2 & 2 \\
3 & 3 \\
\hline
\end{tabular}

\begin{tabular}{|ll|}
\hline 4 & 4 \\
1 & 1 \\
\hline
\end{tabular}

\begin{tabular}{l|}
2 \\
3 \\
\hline
\end{tabular}

\begin{tabular}{lll|llllll|} 
M.1 & gen. & 7,7 & 4 & 3 & 4 & 3 & 2 & 4 \\
M.2 & voc. & 8,2 & 4 & 4 & 3 & 4 & 4 & 5 \\
M.3 voc. & 6,8 & 4 & 4 & 3 & 2 & 3 & 4 \\
M.4 & gen. & 8,3 & 3 & 4 & 2 & 4 & 3 & 4 \\
M.5 voc. & 7,5 & 4 & 4 & 4 & 3 & 3 & 3 \\
M.6 voc. & 7,6 & 3 & 3 & 2 & 2 & 2 & 3 \\
M.7 & gen. & 7,6 & 4 & 3 & 2 & 3 & 2 & 2 \\
\hline
\end{tabular}

\begin{tabular}{|l|}
\hline 4 \\
4 \\
4 \\
1 \\
4 \\
3 \\
3 \\
\hline
\end{tabular}

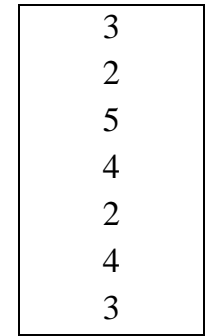

\begin{tabular}{|ll|}
\hline 2 & 2 \\
3 & 2 \\
3 & 2 \\
1 & 2 \\
3 & 3 \\
3 & 4 \\
1 & 2 \\
\hline
\end{tabular}

\begin{tabular}{|ll|}
\hline 2 & 3 \\
1 & 1 \\
1 & 1 \\
2 & 2 \\
1 & 1 \\
1 & 2 \\
1 & 1 \\
\hline
\end{tabular}

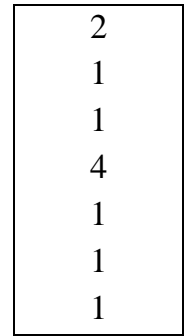

Gr.L

$\begin{array}{ll}\text { L.1 } & \text { gen. } \\ \text { L. } 2 & \text { voc. } \\ \text { L. } 3 & \text { gen. } \\ \text { L.4 } & \text { gen. } \\ \text { L. } 5 & \text { voc. }\end{array}$

\begin{tabular}{l|llllll|}
7,7 & 2 & 1 & 1 & 1 & 1 & 2 \\
8,0 & 2 & 3 & 2 & 1 & 1 & 1 \\
6,6 & 1 & 1 & 1 & 1 & 2 & 3 \\
8,0 & 1 & 1 & 1 & 1 & 1 & 2 \\
8,0 & 1 & 1 & 1 & 1 & 1 & 1 \\
\hline
\end{tabular}
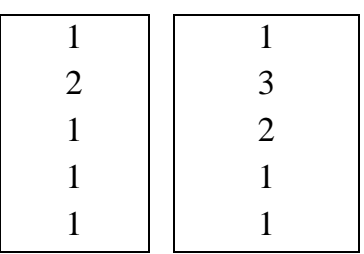

\begin{tabular}{|ll|}
\hline 3 & 2 \\
2 & 2 \\
2 & 2 \\
3 & 2 \\
2 & 1 \\
\hline
\end{tabular}

\begin{tabular}{|ll|}
\hline 2 & 2 \\
1 & 1 \\
1 & 1 \\
3 & 1 \\
2 & 2 \\
\hline
\end{tabular}

\begin{tabular}{l|}
2 \\
1 \\
2 \\
1 \\
1
\end{tabular}

Gr. = group of students with similar overall scores; $\mathrm{H}=$ high; $\mathrm{HM}=$ high/medium; $\mathrm{M}=$ medium; $\mathrm{L}=$ low .

Prior education: voc. $=$ vocational secondary education; gen. $=$ general secondary education.

)* Note: score $1=$ low; score $5=$ high 
Cluster analysis

Hierarchical cluster analysis applied to students revealed four groups, which differed in the overall height of their scores for the 13 aspects: one group $(n=4)$ with overall high scores; one group ( $n=2)$ with a mixture of high and medium scores; one group $(n=7)$ with overall medium scores; and one group $(n=5)$ with overall low scores. The same procedure applied to knowledge quality aspects revealed three clusters of aspects, as well as three stand-alone aspects. The first cluster consisted of six extent- and depth-aspects: relevance, accounting for actions, completeness of narrative, work levels, viewpoints and role awareness. A second cluster contained two aspects: explicit concepts and completeness of structure. A third cluster included two structure-aspects: analytical perspective and complexity. The three stand-alone aspects were: situational facts, unarticulated knowledge and professional language.

In Table 3 the four student groups are displayed on the vertical axis, with the high scoring group on top and the low scoring group at the bottom. The 13 knowledge aspect are displayed on the horizontal axis. Thus table 3 shows the scoring profile of each individual student and group of students. Likewise, the scores for each individual aspect and cluster of aspects are visible. From left to right, aspects show a decreasing number of high and medium scores, indicating that aspects on the left are relatively easier to attain than aspects on the right. Table 3 also shows for which knowledge aspects student groups differ most. Group 1 students (1.1 to 1.4) plus one member of group 2 (2.1) stand out from the rest of the students by scoring high on two aspects: analytical perspective and complexity, both representing knowledge structure. All other students scored low $(n=12)$ or medium $(n=1)$ on both structure aspects. Group 4 students (4.1 to 4.5 ) stand out most from the rest by scoring low on the aspect role awareness. All other students scored high $(n=11)$ or medium $(n=2)$ on this aspect. The narratives of Group 4 students all described difficulties in coping with dilemmas or conflicts about their own roles and/or lack of demarcation of their own role from those of other professionals. 14 Students received low scores for professional language, which was largely due to their use of informal language. This is to some extent confirmed by the scores on explicit concepts, which shows only three high scores, seven medium and eight low scores.

\section{Conceptual clustering}

Apart from the clustering of aspects in Table 3 (primarily based on the height of the scores), we also made a conceptual clustering by sorting the knowledge quality aspects by the four features of expert knowledge: extent, depth, structure, and critical control. Knowledge extent 
combines five aspects representing the number of relevant knowledge elements in the casedescriptions. Knowledge depth combines six aspects representing accuracy and complexity and (multiple) perspectives of case-descriptions. Knowledge structure contains three aspects representing analytical perspective, complexity, and completeness of the structure in the visual maps. Critical control contains two aspects representing the use of formal knowledge terms.

Table 4 depicts for each aspect the cumulative number of high scores ( 4 or 5 on a 5-point scale), medium scores (3) or low scores (1or 2). About two-thirds of the students scored high or medium for aspects of knowledge extent and depth. About one-third scored high or medium for aspects of knowledge structure. Less than one-third scored high or medium for one aspect of critical control: professional language. Less than two-thirds scored high or medium for the second aspect of critical control explicit concepts. For (lack of) critical control it is also interesting to look at the aspect unarticulated knowledge which scored high or medium by two thirds, indicating knowledge being present without the student's conscious awareness. 
Table 4 Cumulative number of low (L), medium $(\mathrm{M})$ and high $(\mathrm{H})$ scores per aspect, with aspects sorted by features of expert knowledge $)^{*}$

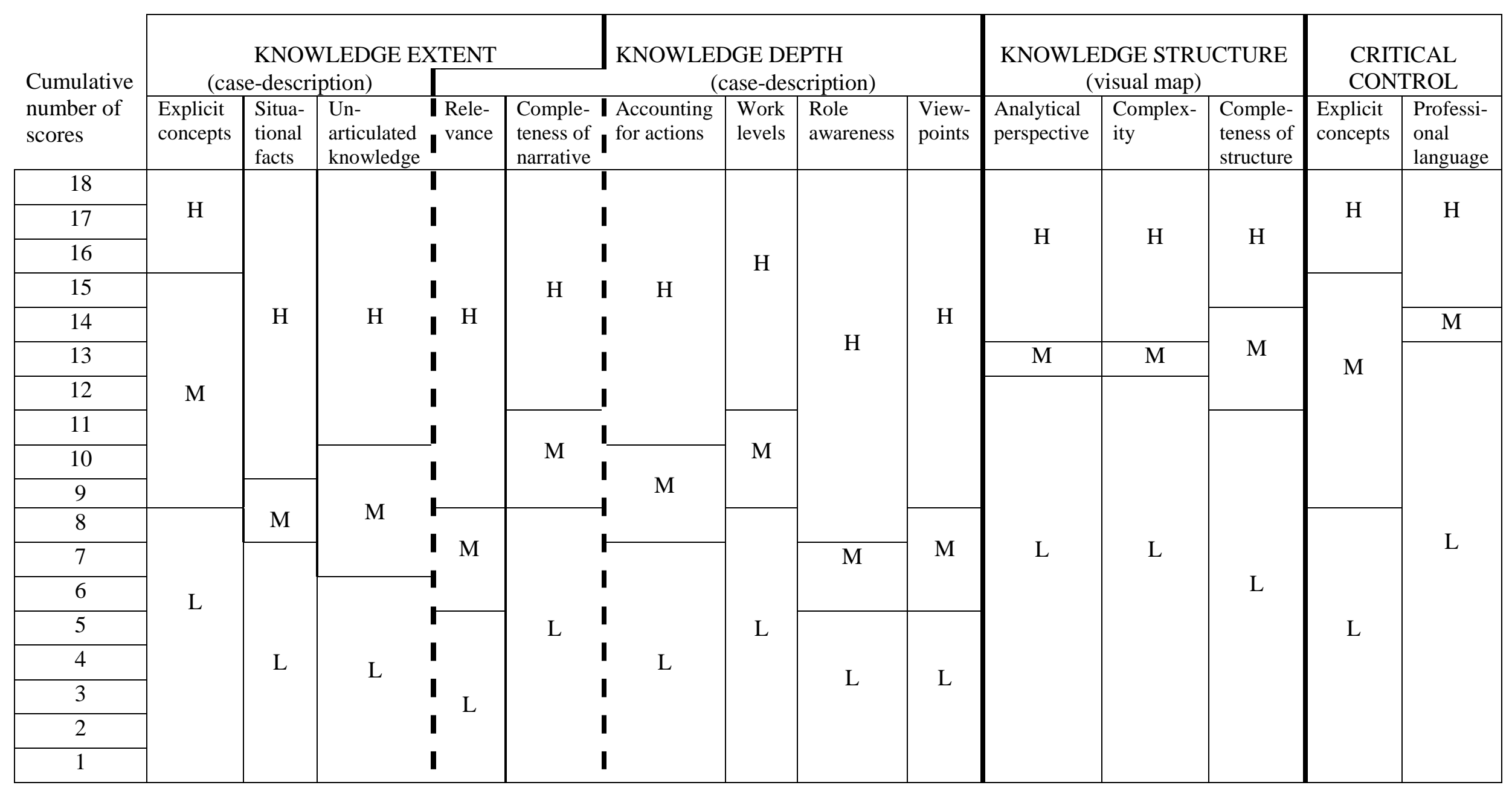

)* Note: H, M and L are students' scores on a 5-point rating scale: $\mathrm{H}=$ high score (4 or 5), $\mathrm{M}$ = medium score (3); $\mathrm{L}=$ low score (1 or 2). 


\section{Discussion and conclusions}

Before discussing the outcomes of our study we will first address methodical issues. Are the instruments and procedures we used for eliciting and appraising students theoretical knowledge in the context of practice valid and reliable? Direct access to social work students' theoretical knowledge in the context of practice is impossible. Social workers cannot thinkaloud while in interaction with clients and colleagues. Indirect access is possible through retrospective reflections, well known to students as a method to explicate knowledge, for example when accounting for actions. Indirect access requires triangulation, using multiple instruments and comparing viewpoints. Multiple instruments were provided by using interviews, concept maps, and a domain knowledge list. Multiple viewpoints were realized by involving senior teachers and domain experts in a six-step procedure for analysis. Asking students to reflect on an own case instead of a standardised case was unusual, but necessary to come as close as possible to real-life practice and the student as a person. Our methods have limitations we are well aware of. As most qualitative methods, they were time-consuming and permitted to question a limited number of students only. However, our instruments and procedures enabled an in-depth exploration valuable for identifying positive and problematic qualities of students' knowledge.

We now arrive at the interpretation of our findings. Is the quality of students' theoretical knowledge in line with what is expected at initial qualification? We found striking differences between groups of students. The knowledge of one group $(n=4)$ was highly appraised for all four quality features, including structure and critical control. The knowledge of three groups $(\mathrm{n}=13)$ was appraised highly for extent and depth. The knowledge of one group $(\mathrm{n}=5)$ received overall low appraisals. Finding differences between students is not surprising in itself, because learning theoretical knowledge as part of professional development is a highly personal process (Daley 2001; Dall'Alba and Barnacle 2007; Hager and Hodkinson 2009). In this process, personal factors interact with elements of instructional design and other contextual factors. However, it is remarkable that we found no correlations between the level of appraisals on the one hand and on the other hand grade-point averages, the results of educational tests, and level of prior education, which is an indicator of cognitive capacities. A possible explanation is that our methods accessed students knowledge-in-practice more closely and personally than educational tests. The low-appraised students, for example, 
seemed inhibited by self-concerns to use the knowledge they had, according to their gradepoint averages, previously demonstrated in educational tests. Their self-concerns affected their performances not only in their cases, but also during their retrospective reflections in the interview and concept map. Though self-concerns are normal for a starting professional, they should not inhibit knowledge use and reflection (Eraut 1994; Van Ewijk 2010). The other participants also encountered role difficulties, but they coped well. Several different explanations are possible: the programme offered the low-appraised students insufficient support; their capabilities were deficient; or the criteria used by the experts in our study were too severe. This raises questions for further research. First, what can realistically be expected of these young adults theoretical knowledge after four years of study? Second, what qualities are required, because of work conditions such as responsibilities, workload, support, and learning opportunities?

Another interesting difference we found is that only the high-appraised students managed to do well on knowledge structure and critical control. Apparently these students thrived well in their constructivist programme and succeeded in building high quality theoretical knowledge. For this group, the critiques uttered in the debates about constructivist learning do not apply. For the majority, however, low scores on knowledge structure and critical control seem to reflect a negative effect of learning knowledge in authentic learning contexts and through self-directed learning. This is an indication that the majority of students need more explicit knowledge instruction and help in recognising theoretical knowledge in practice and explicating it in a well-structured, analytical manner. The latter is a real challenge for practice, as it is known from research that social workers tend to express their knowledge in an informal way, as did our participants (Osmond and O'Connor 2004). We conclude that constructivist learning is not beneficial or adverse for all students alike. In our next study we intend to examine students' personal factors in interaction with the educational programme. 


\section{References}

Alexander, P. A. (2003). The development of expertise: The journey from acclimation to proficiency. Educational Researcher, 32(8), 10-14.

Bereiter, C. (2002). Education and mind in the knowledge age. Mahwah, NJ: Erlbaum.

Bereiter, C., \& Scardamalia, M. (1993). Surpassing ourselves. An inquiry into the nature and implications of expertise. Chicago: Open Court.

Biggs, J. (2003). Teaching for quality learning at university. Maidenhead, UK: Open University Press.

Billett, S. (2001). Learning throughout working life: Interdependencies at work. Studies in Continuing Education, 23(1), 19-35.

Boshuizen, H. P. A. (2004). Does practice make perfect? In H. P. A. Boshuizen, R. Bromme, \& H. Gruber (Eds.), Professional learning: Gaps and transitions on the way from novice tot expert (pp. 73-95). Dordrecht, The Netherlands: Kluwer.

Chi, M. T. H. (1997). Quantifying qualitative analyses of verbal data: A practical guide. The Journal of the Learning Sciences, 6(3), 271-315.

Corbin, J., \& Strauss, A. (2008). Basics of qualitative research. Techniques and procedures for developing grounded theory. Thousand Oaks, CA: Sage.

Cosis Brown, H. (1996). The knowledge base of social work. In A. A. Vass (Ed.), Social work competences. Core knowledge, values and skills (pp. 8-35). London: Sage.

Daley, B. J. (2001). Learning and professional practice: A study of four professions. Adult Education Quarterly, 52(1), 39-54.

Dall'Alba, G., \& Barnacle, R. (2007). An ontological turn for higher education. Studies in Higher Education, 32(6), 679-691.

Edwards, R. (1998). Mapping, locating and translating: a discursive approach to professional development. Studies in Continuing Education, 20(1), 23-38.

Eraut, M. (1994). Developing professional knowledge and competence. Abingdon, UK: RoutlegdeFalmer 
Eraut, M. (2004). Transfer of knowledge between education and workplace settings. In H. Rainbird, A. Fuller, \& A. Munro (Eds.), Workplace learning in context (pp. 201-221). London: Routledge.

Eraut, M. (2012). Developing a broader approach to professional learning. In A. Mc Kee \& M. Eraut (Eds.), Learning trajectories, innovations and identity for professional development (pp. 21-45). Dordrecht, The Netherlands: Springer.

Hager, P., \& Hodkinson, P. (2009). Moving beyond the metaphor of transfer of learning. British Educational Research Journal, 35(4), 619-638.

Kirschner, P. A., Sweller, J., \& Clark, R. (2006). Why minimal guidance during instruction does not work: An analysis of the failure of constructivist, discovery, problem-based, experiential and inquiry-based teaching. Educational Psychologist, 41(2), 75-86.

Lave, J. (2009). The practice of learning. In K. Illeris (Ed.), Contemporary theories of learning (pp. 200-208).London: Routledge.

Maton, K., \& Moore, R. (Eds.). (2010). Social realism, knowledge and the sociology of education. Coalitions of the mind. London: Continuum.

Miles, M. B., \& Huberman, A. M. (1994). Qualitative data analysis. An expanded sourcebook. Thousand Oaks, CA: Sage.

Moust, J., \& Schmidt, H. (1998). Probleemgestuurd onderwijs [Problem-based education]. Groningen, The Netherlands: Wolters-Noordhoff.

Novak, J. D. (1998). Learning, creating and using knowledge. Concept maps as facilitative tools in schools and corporations. Mahwah, NJ: Erlbaum.

Osmond, J., \& O’Connor, I. (2004). Formalizing the unformalized: Practitioners' communication of knowledge in practice. British Journal of Social Work, 34(5), 677-692.

Otto, H.-U., Polutta, A., \& Ziegler, H. (Eds.). (2009). Evidence-based practice - Modernising the knowledge based of social work? Opladen and Farmington Hills, MI: Budrich.

Parton, N., \& O'Byrne, P. (2000). Constructive social work. Towards a new practice. Basingstoke, UK: Palgrave Macmillan.

Payne, M. (2009). Knowledge, evidence and the wise person of practice. In H.-U. Otto, A. Polutta, \& H. Ziegler (Eds.), Evidence-based practice - Modernising the knowledge base of social work? (pp. 77-94). Opladen and Farmington Hills, MI: Budrich. 
Rubin, H. R., \& Rubin, I. S. (2005). Qualitative interviewing. The art of hearing data. Thousand Oaks, CA: Sage.

Ruiz-Primo, M. A. (2004). Examining concept maps as assessment tool. First International Conference on Concept Mapping. http://cmc.ihmc.us/papers/cmc2004-036. Accessed 17 January 2009.

Schmidt, H. G., \& Boshuizen, H. P. A. (1993). On acquiring expertise in medicine. Educational Psychology Review, 5, 1-17.

Schön, D. A. (1983). The reflective practitioner. How professionals think in action. New York: Basic Books.

Sectorraad HSAO. (2008). Vele takken, één stam. Kader voor de hogere sociaal-agogische opleidingen [Many branches, one trunk. A framework for bachelor's programmes for social workers]. Amsterdam: SWP.

Simons, P. R. J., Van der Linden, J., \& Duffy, T. (Eds.). (2000). New learning. Dordrecht, The Netherlands: Kluwer.

Spiro, R. J., \& DeSchryver, M. (2009). Constructivism. When it's the wrong idea and when it's the only idea. In S. Tobias \& T. M. Duffy (Eds.), Constructivist instruction: success or failure? (pp. 106-123). New York: Routledge.

Strasser, J., \& Gruber, H. (2004). The role of experience in professional training and development of psychological counsellors. In H. P. A. Boshuizen, R. Bromme, \& H. Gruber (Eds.), Professional learning: Gaps and transitions on the way from novice to expert (pp. 11-27). Dordrecht, The Netherlands: Kluwer.

Taylor, C., \& White, S. (2000). Practising reflexivity in health and welfare. Making knowledge. Maidenhead, UK: Open University Press.

Tobias, S., \& Duffy, T. M. (Eds.). (2009). Constructivist instruction. Success or failure. New York: Routledge.

Tynjälä, P. (2009). Connectivity and transformation in work-related learning - Theoretical foundations. In M.-L. Stenström \& P. Tynjälä (Eds.), Towards integration of work and learning. Strategies for connectivity and transformation (pp. 11-37). New York: Springer.

Van Ewijk, H. (2010). European social policy and social work. Citizenship-based social work. London: Routledge. 
Van Merriënboer, J. J. G. (1997). Training complex skills. A four-component instructional design model for technical training. Englewood Cliffs, NJ: Educational Technology Publications.

Wenger, E. (1998). Communities of practice: Learning, meaning and identity. Cambridge, MA: Cambridge University Press.

Wheelahan, L. (2010). Why knowledge matters in curriculum. A social realist argument. Abingdon, UK: Routledge.

Yin, R. K. (2003). Case Study Research. Thousand Oaks, CA: Sage. 
Appendix A Criteria for scoring knowledge aspects at initial qualification at bachelor's level and the knowledge features they represent

\begin{tabular}{|c|c|c|c|}
\hline Aspects & Criteria for a low appraisal & Criteria for a high appraisal & $\begin{array}{l}\text { Knowledge } \\
\text { feature }\end{array}$ \\
\hline $\begin{array}{l}\text { Professional } \\
\text { language }\end{array}$ & $\begin{array}{l}\text { Informal language, using lay terms } \\
\text { only. } \\
\text { Language is verbose (a long- } \\
\text { winded story), and concrete only. }\end{array}$ & $\begin{array}{l}\text { Formal language, using } \\
\text { professional terms, including } \\
\text { concepts and methodical terms. } \\
\text { Language is concise, to the point, } \\
\text { abstract as well as concrete. }\end{array}$ & $\begin{array}{l}\text { Critical } \\
\text { Control }\end{array}$ \\
\hline $\begin{array}{l}\text { (Number of) } \\
\text { Explicit } \\
\text { concepts }\end{array}$ & $\begin{array}{l}\text { Less than } 15 \text { conceptual terms } \\
\text { counted in case description. }\end{array}$ & $\begin{array}{l}\text { More than } 45 \text { conceptual terms } \\
\text { counted in case description. }\end{array}$ & $\begin{array}{l}\text { Critical } \\
\text { Control + } \\
\text { Extent }\end{array}$ \\
\hline $\begin{array}{l}\text { Unarticulated } \\
\text { knowledge }\end{array}$ & $\begin{array}{l}\text { Actions seem random (trial and } \\
\text { error). } \\
\text { Inadequate actions and } \\
\text { deliberations, revealing no } \\
\text { underlying theoretical knowledge } \\
\text { and an inadequate approach for } \\
\text { the case. Unarticulated theoretical } \\
\text { knowledge is recognisable in none } \\
\text { or very few actions and } \\
\text { deliberations. }\end{array}$ & $\begin{array}{l}\text { Descriptions of adequate actions } \\
\text { and deliberations, and a } \\
\text { methodical approach reveal } \\
\text { underlying theoretical } \\
\text { knowledge, adequate for the } \\
\text { case. Unarticulated theoretical } \\
\text { knowledge is recognisable in } \\
\text { most actions and deliberations. }\end{array}$ & Extent \\
\hline $\begin{array}{l}\text { (Range of) } \\
\text { Situational } \\
\text { facts }\end{array}$ & $\begin{array}{l}\text { A small number of situational } \\
\text { facts is described, limited to a } \\
\text { narrow context (mostly of clients } \\
\text { and oneself). }\end{array}$ & $\begin{array}{l}\text { A large number of situational } \\
\text { facts is described, comprising a } \\
\text { broad context (including that of } \\
\text { clients, oneself, one's } \\
\text { organisation and society). }\end{array}$ & Extent \\
\hline $\begin{array}{l}\text { (Professional) } \\
\text { Relevance } \\
\text { (of content) }\end{array}$ & $\begin{array}{l}\text { Superficial, incoherent mentioning } \\
\text { of elements with no explanations. } \\
\text { Random actions, trial and error, } \\
\text { without deliberations. Either too } \\
\text { limited (leaving essentials out), or } \\
\text { too extended (too many details). }\end{array}$ & $\begin{array}{l}\text { In-depth, coherent mentioning of } \\
\text { elements, with elaborate } \\
\text { explanations. Deliberated, } \\
\text { methodical actions, focused on } \\
\text { goals. Focused on essential } \\
\text { elements. }\end{array}$ & $\begin{array}{l}\text { Extent }+ \\
\text { Depth }\end{array}$ \\
\hline $\begin{array}{l}\text { Completeness } \\
\text { of narrative }\end{array}$ & $\begin{array}{l}\text { Elements which are essential for } \\
\text { understanding the situation-at- } \\
\text { hand are left out of the } \\
\text { description. For example: some of } \\
\text { the relevant actors, parts of their } \\
\text { situations and/or the broader } \\
\text { context and/or relevant } \\
\text { (methodical) actions are missing. }\end{array}$ & $\begin{array}{l}\text { Rich description of the situation- } \\
\text { at-hand, including } \\
\text { all relevant actors, their } \\
\text { immediate situation and broader } \\
\text { context; } \\
\text { all relevant (methodical) actions. }\end{array}$ & $\begin{array}{l}\text { Extent + } \\
\text { Depth }\end{array}$ \\
\hline $\begin{array}{l}\text { (Number of) } \\
\text { Work levels }\end{array}$ & $\begin{array}{l}\text { Only one work level (personal; } \\
\text { organisational; societal) is } \\
\text { mentioned and even this level is } \\
\text { treated in a narrow way. }\end{array}$ & $\begin{array}{l}\text { All three work levels (personal; } \\
\text { organisational; societal) are } \\
\text { mentioned and elaborated upon, } \\
\text { with connections between the } \\
\text { work levels. }\end{array}$ & Depth \\
\hline $\begin{array}{l}\text { Accounting for } \\
\text { actions }\end{array}$ & $\begin{array}{l}\text { Limited accounting for actions; } \\
\text { little explicit mentioning of } \\
\text { deliberations and/or explanations. }\end{array}$ & $\begin{array}{l}\text { Actions are accounted for by } \\
\text { explicit and elaborate } \\
\text { deliberations and explanations. }\end{array}$ & Depth \\
\hline $\begin{array}{l}\text { (Differentiation } \\
\text { in) Viewpoints }\end{array}$ & $\begin{array}{l}\text { Only one actor's viewpoint is } \\
\text { elaborated upon, possibly the }\end{array}$ & $\begin{array}{l}\text { Viewpoint of actors at all work } \\
\text { levels are mentioned, considered }\end{array}$ & Depth \\
\hline
\end{tabular}




\begin{tabular}{|c|c|c|c|}
\hline Aspects & Criteria for a low appraisal & Criteria for a high appraisal & $\begin{array}{l}\text { Knowledge } \\
\text { feature }\end{array}$ \\
\hline & $\begin{array}{l}\text { student's own viewpoint. Only } \\
\text { one way of looking at matters, no } \\
\text { other viewpoints are considered. }\end{array}$ & $\begin{array}{l}\text { and dealt with. } \\
\text { Matters are looked at from } \\
\text { different angles and viewpoints }\end{array}$ & \\
\hline Role awareness & $\begin{array}{l}\text { No mentioning of reciprocal } \\
\text { influences of own and other } \\
\text { actor's roles. Own role and } \\
\text { influence on events or behaviour } \\
\text { is not recognised, things happen to } \\
\text { the student. Passive attitude, own } \\
\text { role is not adjusted. } \\
\text { No awareness of limitations of } \\
\text { own tasks and responsibilities. }\end{array}$ & $\begin{array}{l}\text { Systemic view on own and other } \\
\text { actors' roles involved in the case. } \\
\text { Own role and influence on } \\
\text { events or behaviour is recognised } \\
\text { and accounted for. Active } \\
\text { attitude and role adjustment } \\
\text { when things don't go as initially } \\
\text { expected. } \\
\text { Awareness of own professional } \\
\text { tasks and responsibilities and } \\
\text { limitations. }\end{array}$ & Depth \\
\hline $\begin{array}{l}\text { Analytical } \\
\text { perspective }\end{array}$ & $\begin{array}{l}\text { Visual map is descriptive only, } \\
\text { merely depicting actors and } \\
\text { actions, without methodical } \\
\text { connections between analysis, } \\
\text { goals, actions and outcomes. }\end{array}$ & $\begin{array}{l}\text { Visual map is descriptive and } \\
\text { analytic: elements in the map are } \\
\text { connected in a methodical way: } \\
\text { feedback loops between } \\
\text { analyses, goals, actions and } \\
\text { outcomes. Connections are } \\
\text { explained. }\end{array}$ & Structure \\
\hline Complexity & $\begin{array}{l}\text { Simple linear, temporal structure ( } \\
\text { 'and then, and then - story'). No } \\
\text { feedback loops. Only one level } \\
\text { (micro or meso) is depicted. } \\
\text { Arrows depict one-way influences } \\
\text { only. }\end{array}$ & $\begin{array}{l}\text { Complex, circular, systemic } \\
\text { structure, with feedback loops. } \\
\text { Map depicts an explanation of } \\
\text { processes. Arrows depict } \\
\text { reciprocal influences. Three } \\
\text { work levels (personal; } \\
\text { organisational; societal) are } \\
\text { depicted and connected. The map } \\
\text { contains the essence of the } \\
\text { narrative and is an abstraction of } \\
\text { the narrative. }\end{array}$ & Structure \\
\hline $\begin{array}{l}\text { Completeness } \\
\text { of structure }\end{array}$ & $\begin{array}{l}\text { Important methodical elements } \\
\text { and/or connections are missing. } \\
\text { Only one-way connections. } \\
\text { Connections between work levels } \\
\text { are missing. }\end{array}$ & $\begin{array}{l}\text { Important methodical elements } \\
\text { are represented. Connections are } \\
\text { reciprocal. All work levels } \\
\text { (personal; organisational; } \\
\text { societal) are mentioned and } \\
\text { interconnected. }\end{array}$ & Structure \\
\hline
\end{tabular}


Appendix B Examples of qualitative analysis of case-description with references to student interview-protocol

\begin{tabular}{|c|c|c|c|c|}
\hline \multicolumn{5}{|c|}{ Examples 1 - Knowledge aspect: (Professional) Relevance of knowledge elements in case description } \\
\hline Student & Score & Summary & Experts' quotations & Student-protocol \\
\hline HM2 & 5 & $\begin{array}{l}\text { This student mentions } \\
\text { very relevant facts, } \\
\text { actions \& choice } \\
\text { deliberations and a } \\
\text { background view on } \\
\text { matters. While } \\
\text { describing a } \\
\text { cooperation problem, } \\
\text { she does not lose sight } \\
\text { of the project aims. } \\
\text { Factors influencing the } \\
\text { problem are } \\
\text { mentioned, as well as } \\
\text { her actions to improve } \\
\text { cooperation. Although } \\
\text { relevant concepts are } \\
\text { not mentioned } \\
\text { spontaneously, they } \\
\text { are added after } \\
\text { marking the structured } \\
\text { domain knowledge } \\
\text { list. }\end{array}$ & $\begin{array}{l}\text { "At the end of her story, } \\
\text { you can see she is aware } \\
\text { of positions, roles, } \\
\text { capacities, qualities, } \\
\text { personalities and their } \\
\text { influences." "She knows } \\
\text { what she is doing and } \\
\text { what her aim is." } \\
\text { "She expresses her view } \\
\text { on developmental aid: } \\
\text { bringing a fishing-rod } \\
\text { instead of a fish. I found } \\
\text { that an important } \\
\text { statement." }\end{array}$ & $\begin{array}{l}\text { "For in fact it is a group- and } \\
\text { team-development process. ... } \\
\text { I could have paid more } \\
\text { attention to that process in my } \\
\text { coordinating role. That might } \\
\text { have prevented the cooperation } \\
\text { problem. If we had developed } \\
\text { the feeling of being a group } \\
\text { more than we did, like that we } \\
\text { could have said anything to } \\
\text { each other. But that also has to } \\
\text { do with the relationships } \\
\text { between people." } \\
\text { "I put her in charge at the day } \\
\text { of the event, and in this role } \\
\text { she could show her } \\
\text { capabilities." } \\
\text { "Sustainability means that } \\
\text { things should go on [after you } \\
\text { leave].....My view on } \\
\text { developmental aid is that, well, } \\
\text { you could tell them what to do, } \\
\text { but if you want them to do it } \\
\text { on their own, or if you want } \\
\text { them to develop, you have to } \\
\text { give them the chance to do it } \\
\text { themselves." }\end{array}$ \\
\hline M5 & 3 & $\begin{array}{l}\text { This student mentions } \\
\text { relevant facts } \\
\text { (observations of the } \\
\text { client), actions and } \\
\text { choice deliberations, } \\
\text { He has some strong } \\
\text { views of his own on } \\
\text { which actions to take } \\
\text { and how, which are } \\
\text { not wholly in } \\
\text { accordance with the } \\
\text { professional standards. }\end{array}$ & $\begin{array}{l}\text { "His remark on the } \\
\text { parent's influence was a } \\
\text { relevant observation." } \\
\text { "He has a clear idea of } \\
\text { the process and the } \\
\text { competencies he needs } \\
\text { to fulfil his role." "He } \\
\text { did not agree with his } \\
\text { supervisor on what } \\
\text { action to take." "He } \\
\text { wants to work } \\
\text { independently; he } \\
\text { doesn't seem to realise } \\
\text { the importance of } \\
\text { checking with a } \\
\text { colleague [a protocol, } \\
\text { which is important in } \\
\text { this legal context]." }\end{array}$ & $\begin{array}{l}\text { "This report has standard } \\
\text { headings, and you have to } \\
\text { insert specific data, and then } \\
\text { you have to summarise and } \\
\text { state your own judgment and } \\
\text { advice." } \\
\text { "Yes, during the conversation } \\
\text { [with the clients] I would have } \\
\text { asked other things [other than } \\
\text { my supervisor did], and maybe } \\
\text { I would have pursued things } \\
\text { further. For instance about the } \\
\text { father smoking pot." "I should } \\
\text { have asked my supervisor to } \\
\text { sign the report, but I didn't." } \\
\text { "Our advice was not adopted } \\
\text { [by the judge]; there are all } \\
\text { kinds of rules, and it turned out } \\
\text { our advise didn't fit these rules } \\
\text { exactly." }\end{array}$ \\
\hline
\end{tabular}


Marijke van Bommel is a faculty member of the Institute of Social Studies of HANUniversity, Nijmegen, The Netherlands. She is a PhD candidate at CELSTEC, OUNL.

Henny P. A. Boshuizen is a full professor at Celstec, OUNL, where she is the director of the master programme Learning Sciences. Her main research focus is the development of expertise in a variety of professional domains.

Kitty Kwakman is a member of the board of governors of Zuyd University of Applied Sciences. She specialized in professional learning within social work and education. 